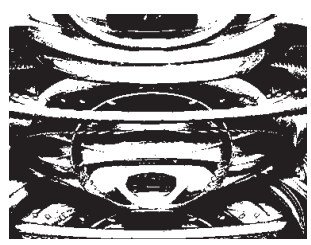

\title{
FORMIRANJE GLOBALNE RETROSPEKTIVNE EVALUACIJE: ZANEMARIVANJE TRAJANJA ISKUSTVA I PRAVILO VRHUNCA I KRAJA
}

Kosta BOVAN

Zagreb

UDK: 159.9:165.195

Pregledni rad

Primlieno: 3. 11. 2011

"Ticking away the moments that make up a dull day" Pink Floyd - Time; Dark side of the moon, 1973.

Utjecai prošlih iskustava na buduće odluke ovisi o tome kako smo ta iskustva evaluirali. Prilikom ispitivanja odnosa niza trenutačnih i globalnih retrospektivnih procjena ustanovljeno je kako globalne evaluacije ne sadrže informacije o duljini događaja. Drugim riječima, liudi su skloni zanemarivanju trajanja iskustva. Osim toga, pokazalo se da liudi najčešće slijede pravilo vrhunca i kraja, odnosno globalne procjene temelje isključivo na najintenzivnijem i posljednjem trenutku iskustva. U radu su izneseni rezultati najvažnijih eksperimentalnih istraživanja, ali i istraživanja provedenih u realnim uvjetima. Opisane su paradigme trenutačne evaluacije i procjene prema prototipu te detalii primijenjenih metodologija. Istaknuta je rasprava o normativnosti zanemarivanja trajanja. Unatoč tome što su navedeni fenomeni potvrđeni u mnogim domenama, naveden je i niz nalaza i teoretskih pretpostavki koji dovode u pitanje njihovu učestalost. Na kraju članka raspravlja se o možebitnim preskripcijama kojima bi se poboljšala kvaliteta iskustava.

Ključne riječi: zanemarivanje trajanja, pravilo vrhunca i kraja, trenutačne evaluacije, procjena prema prototipu, afektivne evaluacije

$\triangle \quad$ E-mail: kosta.bovan@gmail.com

\section{UVOD}

Bilo da odabiremo jelo u restoranu, odjeću koju ćemo odjenuti ili grad u kojem ćemo živjeti, donošenje odluka je neizbježno. No na koji način donosimo odluke? Što sve utječe na naše odabire? U standardnom ekonomskom modelu ova se pitanja 
DRUŠ. ISTRAŽ. ZAGREB GOD. 22 (2013), BR. 2, STR. 325-345

BOVAN, K.:

FORMIRANJE

GLOBALNE... zanemaruju. U skladu s načelima biheviorizma, analiza odluka usmjerena je na ponašanje, odnosno na sam čin odluke osoba se odlučila za određeni izbor jer ga preferira. Drugim riječima, standardni ekonomski model zaobilazi "crnu kutiju" (Camerer, Loewenstein i Prelec, 2005 ). Kao svojevrstan odgovor postojećem modelu razvilo se područje bihevioralne ekonomije, nastalo spajanjem ekonomskih ideja i psiholoških spoznaja te metodologije. Bihevioralni ekonomisti usmjereni su na proučavanje faktora koji utječu na proces odlučivanja, a nisu zahvaćeni standardnim modelom. Jedna od takvih tema jest utjecaj prošlih iskustava, odnosno njihovih afektivnih evaluacija, na buduće odluke. Važnost afektivnih evaluacija očita je - ugodna iskustva želimo ponoviti, a ona neugodna izbjeći. Postavlja se pitanje kako formiramo retrospektivne evaluacije. Za iskustva koja se ne protežu kroz vrijeme (poput gledanja fotografije, čitanja rečenice teksta ili kušanja zalogaja hrane), situacija je jasna - evaluacija navedenih iskustava jedinstvenog je intenziteta i valencije. No naša svakodnevica puna je iskustava koji se protežu kroz vrijeme, poput gledanja filma, čitanja knjige ili jedenja jela. Ta iskustva predstavljaju niz trenutaka čiji se doživljaji razlikuju po intenzitetu, a ponekad i po valenciji. Intuitivno bismo mogli reći kako je globalna evaluacija iskustva koje se proteže kroz vrijeme prosjek evaluacija svih trenutaka koji čine to iskustvo. Film ćemo retrospektivno smatrati ugodnim u jednakoj mjeri kao i prosjek naših evaluacija ugode pojedinih trenutaka filma. Međutim, naša intuicija pokazala bi se pogrešnom. Naime, mnogim istraživanjima pokazalo se kako ljudi globalne retrospektivne evaluacije formiraju isključivo na temelju nekoliko geštalt karakteristika niza trenutaka (Ariely i Carmon, 2000). Dvije su skupine tih karakteristika. Prva se tiče konfiguracije sekvence i uključuje trend od lošijega prema boljem ili od boljega prema lošijem (Loewenstein i Prelec, 1993), brzinu promjene (Hsee i Abelson, 1991) i promjenu u brzini promjene ili kvaziakceleraciju (Hsee, Salovey i Abelson, 1994). Druga skupina karakteristika na koje se ljudi obaziru jesu intenziteti u specifičnim trenucima, točnije $\mathrm{u}$ trenutku s najjačim intenzitetom (vrhunac, eng. peak) i u zadnjem trenutku iskustva. $U$ nizu istraživanja ova skupina karakteristika pokazala se izrazito jakim prediktorom retrospektivne globalne evaluacije i uvriježio se naziv pravilo vrhunca i kraja (eng. peak-end rule) (Frederickson i Kahneman, 1993). Zanimljiv nalaz koji se ponovio u nizu istraživanja jest da se ljudi, prilikom formiranja globalne retrospektivne evaluacije, ne obaziru na trajanje iskustva. Ovaj fenomen postao je poznat pod nazivom zanemarivanje trajanja (eng. duration neglect) (Frederickson i Kahneman, 1993). 
U ovom radu dajemo pregled nalaza zanemarivanja trajanja te pravila vrhunca i kraja. Obradit ćemo najvažnije nalaze, teoretska objašnjenja, ali i alternativne pristupe navedenim fenomenima te smjernice za buduća istraživanja.

\section{ZANEMARIVANJE TRAJANJA}

Istražujući odnos globalnih evaluacija i niza evaluacija pojedinih trenutaka, Varey i Kahneman (1992) došli su do potpuno neočekivanih rezultata - trajanje iskustva imalo je minimalan utjecaj na opću procjenu iskustva. Sudionici su promatrali niz procjena neugodnosti koje su svakih 5 minuta donosili sudionici u drugom eksperimentu, a zadatak im je bio da procijene ukupnu neugodnost iskustva. Naravno, autori su izmislili nizove s različitim trendom, trajanjem i rasponom procjena. Rezultati su pokazali kako je efekt trajanja bio minimalan u odnosu na efekte ostalih karakteristika. Primjerice, sudionici su iskustva koja su trajala 35 minuta procijenili neugodnijima za samo 4 boda (na skali od 0 do 100) od iskustava koja su trajala 15 minuta i imala jednak raspon i trend (nizovi su bili prezentirani tako da je ukupno trajanje iskustva bilo istaknuto). Za razliku od navedenog istraživanja, u kojem su sudionici donosili samo globalne evaluacije utemeljene na izmišljenim podacima, $\mathrm{u}$ istraživanju Frederickson i Kahneman (1993) donosili su i trenutačne i globalne evaluacije. Sudionici su gledali filmove raznih tematika koji su se razlikovali po valenciji, intenzitetu i trajanju, a zadatak im je bio u realnom vremenu iskazivati (ne)ugodu koju osjećaju. Pošto su pogledali film, morali su izraziti svoj globalni afektivni doživljaj. Rezultati su pokazali kako su sudionici prilikom davanja retrospektivnih evaluacija ugodnih filmova potpuno zanemarivali trajanje. Na procjene neugodnih filmova trajanje je imalo izrazito slab utjecaj, što su autori objasnili eskalacijom negativnog afekta kroz vrijeme. Budući da u svakodnevici ne razmišljamo (svjesno) svaki trenutak o tome kako se osjećamo, autore je zanimalo jesu li dobiveni rezultati metodološki artefakt. Stoga su u drugom eksperimentu sudionici samo gledali filmove te im nije rečeno da će na kraju eksperimenta filmove globalno vrednovati. Jednako kao i u prvom eksperimentu, procjene sudionika nisu bile povezane s trajanjem iskustva, što je rezultat koji potvrđuje postojanje zanemarivanja trajanja neovisno o karakteristikama eksperimenta. Procedura ovog eksperimenta tipična je za istraživanja na ovom području.

Potpuno ili djelomično zanemarivanje trajanja potvrđeno je $\mathrm{u}$ istraživanjima $\mathrm{u}$ kojima su sudionici trpjeli bol (Kahneman, Frederickson, Schreiber i Redelmeier, 1993; Ariely, 1998), slušali neugodne zvukove (Ariely, 1998; Ariely i Loewenstein, 2000; Schreiber i Kahneman, 2000), slušali poznatu ili klasičnu 
DRUŠ. ISTRAŽ. ZAGREB GOD. 22 (2013), BR. 2, STR. 325-345

BOVAN, K.:

FORMIRANJE

GLOBALNE.. glazbu (Rozin, Rozin i Goldberg, 2004), jeli ili zamišljali kako jedu (Rode, Rozin i Durlach, 2007), procjenjivali privlačnost niza monetarnih transakcija (Langer, Sarin i Weber, 2005), procjenjivali kvalitetu televizijskoga prijenosa (Hands i Avons, 2001) i gledali televizijske reklame (Baumgartner, Sujan i Padgett, 1997). Osim eksperimentalne provjere, fenomen zanemarivanja trajanja potvrđen je i u realnim uvjetima. Primjerice, Redelmeier i Kahneman (1992; prema Frederickson i Kahneman, 1993) tražili su pacijente podvrgnute kolonoskopiji, izrazito bolnoj proceduri, da procijene količinu boli koju su pretrpjeli za trajanja pregleda. Iako je trajanje same procedure variralo od 4 do 69 minuta, ono nije utjecalo na retrospektivne evaluacije. Navedeni rezultati pokazuju da ljudi prilikom retrospektivne evaluacije iskustava koja se protežu kroz vrijeme zanemaruju ili pridaju izrazito malu važnost trajanju iskustva.

\section{TRENUTAČNA EVALUACIJA KAO TEORETSKI OKVIR}

Istraživanja zanemarivanja trajanja odvijaju se u okvirima paradigme iskustvene vrijednosti (eng. experienced utility), koja se odnosi na stupanj ugode ili neugode koje određeno iskustvo izaziva ili je izazvalo kod pojedinca (Kahneman, 2000a). Tu je ideju u ekonomiju uveo u 18. stoljeću Jeremy Bentham (1789; prema Kahneman, Wakker i Sarin, 1997), no do 20. stoljeća takav pristup vrijednosti potpuno se odbacuje. Naime, osim što se smatralo da se subjektivni doživljaj ugode ne može mjeriti, smatralo se i da promatranjem izbora ljudi možemo dobiti dovoljno informacija o tome što osobe smatraju vrijednim. Kada osoba izabire, očito bira nešto što joj je vrijedno, jer zašto bi inače tako odabrala? Ove se pretpostavke temelje na ideji da su ljudi potpuno racionalni akteri i maksimizatori vrijednosti te da njihov izbor dovodi do optimizirane razine ugode (Kahneman i sur., 1997). Međutim, razvojem područja bihevioralne ekonomije postalo je jasno da se ljudi tako ne ponašaju. Primjerice, skloni smo smatrati kako je nakon niza pisama veća vjerojatnost da se na bačenom novčiću pojavi glava, pojava poznata pod nazivom kockarska pogreška (eng. gambler's fallacy) (Baron, 2008). Drugim riječima, ljudi su skloni donošenju odluka sa suboptimalnim posljedicama. Većina odluka koje su bihevioralni ekonomisti analizirali bila je usmjerena prema budućnosti. Ipak, skupina istraživača, na čelu s Danielom Kahnemanom, smatrala je kako primjena Benthamova pristupa vrijednosti može pridonijeti našem shvaćanju procesa donošenja odluka. Stoga uvode trenutačnu evaluaciju (eng. evaluation by moments - vidi Kahneman, 2000a), teoretski okvir koji uključuje koncepte trenutačne, ukupne i retrospektivne vrijednosti (Kahneman i sur., 1997). Unatoč nesuglasicama oko nalaza i određenih teoretskih pretpostavki, istraživači na 
DRUŠ. ISTRAŽ. ZAGREB GOD. 22 (2013), BR. 2 STR. 325-345

BOVAN, K.: FORMIRANJE GLOBALNE.. ovom području slažu se kako je trenutačna evaluacija adekvatan teoretski okvir za analiziranje pojava vezanih uz iskustvenu vrijednost (Ariely, Kahneman i Loewenstein, 2000). Objasnit ćemo koncepte vrijednosti uz pomoć scenarija. Zamislite ovakvu situaciju - Vaš prijatelj planira putovanje. Kako ste Vi prošle godine bili na mjestu na koje on želi ići, zanima ga kako Vam je bilo. Prijatelju ste dali procjenu i toplo preporučili hotel u kojem treba odsjesti. Međutim, on Vas podsjeti da ste na tom putovanju sa sobom imali "hedonimetar" - uređaj na kojem ste svaki trenutak putovanja označavali koliko ste sretni. Budući da je Vaš prijatelj znanstvenik, predlaže mali eksperiment - zanima ga stupanj slaganja Vaše retrospektione procjene s prosječnom vrijednosti rezultata hedonimetra. Pristajete, ali već u idućem trenutku shvaćate da je prosjek Vaših trenutačnih procjena zadovoljstva izrazito niži od Vaše globalne retrospektivne procjene.

Trenutačna vrijednost odnosi se na valenciju i intenzitet afektivnog iskustva u određenom trenutku, a može se mjeriti samoprocjenama ili fiziološkim mjerama, odnosno u našem primjeru hedonimetrom (Kahneman, 2000a). Argument kako se subjektivan doživljaj ugode ne može mjeriti Kahneman i suradnici (1997) smatraju netočnim. Ističu kako je ispitivanje subjektivne ugode identično mjerenju percipirane glasnoće ili temperature. Primjerice, ako razne osobe pitamo da procijene doživljaj temperature u prostoriji, dobivamo poprilično uniformne odgovore. Jednako tako, razne osobe daju slične procjene neugodnosti električnoga šoka. Možemo zaključiti kako je subjektivan doživljaj ugode u jednakoj mjeri valjan (i mjerljiv) kao i subjektivni doživljaji senzornih modaliteta.

U navedenim istraživanjima trenutačna vrijednost mjerila se tako da su sudionici svakih nekoliko sekundi ili konstantno pomoću računala označavali trenutačnu razinu negativnog afekta (Frederickson i Kahneman, 1993), boli (Ariely, 1998), percipirane kvalitete televizijskoga prijma (Hands i Avons, 2001) i slično. Međutim, valja istaknuti kako se primjena trenutačnih mjera temelji na dvije implicitne pretpostavke - ljudi točno izjavljuju o trenutačnim doživljajima, pa primjena ovih mjera ne utječe na rezultate (Ariely i Carmon, 2000). Čak i kada se prihvati točnost prve pretpostavke, druga je pretpostavka teoretska i metodološka poteškoća. Naime, postoje dokazi koji govore u prilog tome da primjena trenutačnih mjera ne utječe na rezultate (Frederickson i Kahneman, 1993; Baumgartner i sur., 1997), ali postoje i nalazi koji pokazuju kako primjena tih mjera smanjuje utjecaj trenda (Ariely i Zauberman, 2000) i generalno smanjuje procjenu intenziteta (Ariely, 1998). Alternativa ovom pristupu jest upotreba objektivnih mjera, uz pretpostavku kako se sekvenca objektivnih intenziteta podražaja podudara sa subjektivnim doživljajem. Za razliku od primje- 
DRUŠ. ISTRAŽ. ZAGREB GOD. 22 (2013), BR. 2, STR. 325-345

BOVAN, K.:

FORMIRANJE

GLOBALNE... ne mjera trenutačnih vrijednosti, ovakav pristup ima problema s adaptacijom na intenzitete te efekte primarnosti i recentnosti (Ariely i Carmon, 2000). Ostaje otvoreno pitanje zahvaćaju li ova dva pristupa različite psihološke mehanizme, a ako je to točno, odabir bi se trebao temeljiti na tome jesu li trenutačne mjere prikladne za specifičnu domenu podražaja. Stoga, za sada, Ariely i Carmon (2000) predlažu obje metode. Schreiber i Kahneman (2000) su, primjerice, u predistraživanju pokazali kako su sekvence objektivnih intenziteta neugodnih zvukova u stabilnom odnosu sa subjektivnim procjenama, što je rezultat koji im je dao opravdanje za upotrebu objektivnih intenziteta kao zamjenu za trenutačnu vrijednost. Autori napominju kako je nužna empirijska validacija ovog odnosa prije svakog istraživanja.

Ukupna je vrijednost normativni koncept totalne vrijednosti sekvence koja se temelji na trenutačnim vrijednostima ${ }^{1}$ (Kahneman i sur., 1997). Za razliku od klasičnih ekonomskih modela, koji analizu vrijednosti sekvence provode nad cjelokupnim epizodama, ukupna vrijednost uzima $u$ analizu trenutačne vrijednosti. Valja naglasiti dvije pretpostavke koje se tiču ovoga koncepta. Prva je da na ukupnu vrijednost ne utječe raspored trenutačnih vrijednosti. Ova je pretpostavka u skladu s idejom o trenutačnoj vrijednosti. Naime, sudionici prilikom procjenjivanja trenutačnih vrijednosti (svjesno ili nesvjesno) uzimaju u obzir sve efekte redoslijeda podražaja, poput primarnosti, recentnosti ili adaptacije. Zbog toga redoslijed trenutačnih vrijednosti ne utječe na ukupnu vrijednost. Druga pretpostavka ističe kako svi trenuci u sekvenci imaju jednaku težinu (važnost) za ukupnu vrijednost (za detaljniju analizu normativnih principa ukupne vrijednosti vidi Kahneman i sur., 1997). Važnost ove ideje bit će istaknuta kasnije prilikom analize pravila vrhunca i kraja. Ukupna vrijednost $u$ istraživanjima najčešće se operacionalizirala kao prosjek trenutačnih vrijednosti, što je u skladu s laičkim intuicijama o ukupnoj vrijednosti iskustva (Cojuharenco, 2007).

Retrospektivna vrijednost odnosi se na globalnu evaluaciju proteklog iskustva (Kahneman, 2000a) ili, laički rečeno, odgovor na pitanje "Kako ti je bilo?" Naravno, kao što je već navedeno, intuitivno možemo pretpostaviti da ljudi daju valjane odgovore na pitanja ove vrste koji su u skladu s ukupnom vrijednosti iskustva - veći prosjek pritom znači veću (ne) ugodu. Međutim, istraživanja pokazuju kako ljudi formiraju globalne retrospektivne evaluacije na temelju pravila vrhunca i kraja, a prosjek trenutačnih evaluacija lošije opisuje retrospektivnu vrijednost epizode (vidi pod "Pravilo vrhunca i kraja"). Zbog ovih "pogrešaka" u retrospektivnim evaluacijama ukupna se vrijednost počela uzimati kao mjerilo "objek- 
DRUŠ. ISTRAŽ. ZAGREB GOD. 22 (2013), BR. 2 STR. 325-345

BOVAN, K.: FORMIRANJE GLOBALNE.. tivne sreće" ili kvalitete života (Kahneman, 2000b). Ipak, valja imati na umu kako ljudi odluke o budućnosti donose na temelju retrospektivne vrijednosti. Hoćemo li ponovno posjetiti Las Vegas, ovisi o našoj retrospektivnoj evaluaciji iskustva koje se prisjetimo prilikom odlučivanja. Zanimljivi su rezultati istraživanja u kojem su sudionici predviđali ugodnost svojega putovanja, davali trenutačne evaluacije tijekom te retrospektivne evaluacije nakon putovanja. Pokazalo se kako su razine pozitivnog i negativnog afekta bile veće prilikom predviđanja i sjećanja na iskustvo nego tijekom samog iskustva (Wirtz, Kruger, Scollon i Diener, 2003). Također, jedini prediktor koji se pokazao značajnim za želju sudionika da ponove iskustvo bila je retrospektivna vrijednost iskustva. Stoga, ovisno o cilju istraživanja, treba primjenjivati razne mjere evaluacije iskustava.

\section{NORMATIVNOST ZANEMARIVANJA TRAJANJA}

Zašto ljudi zanemaruju trajanje pri donošenju globalnih retrospektivnih procjena? Intuitivno bismo mogli reći kako ne percipiraju trajanje iskustva ili ga se ne sjećaju pa se prilikom evaluacije ne mogu služiti tom informacijom. Međutim, u nizu istraživanja autori su pokazali kako se ljudi poprilično točno dosjećaju trajanja iskustva (Frederickson i Kahneman, 1993; Kahneman i sur., 1993; Hands i Avons, 2001). Ovi nalazi naveli su Kahnemana i njegove suradnike (Kahneman, 2000a; Schrieber i Kahneman, 2000; Kahneman i Frederick, 2002) da trenutačnu evaluaciju opišu unutar širega teoretskog okvira procjene prema prototipu (eng. judgment by prototype), a zanemarivanje trajanja kao specifičnu vrstu zanemarivanja ekstenzije (eng. extension neglect). Procjena prema prototipu temelji se na ideji da ljudi formiraju prototipe raznih kategorija i čuvaju ih u pamćenju za naknadnu upotrebu, a primjer toga jesu stereotipi. Prilikom donošenja odluka o nekoj kategoriji orijentiramo se na relevantna svojstva prototipa te zanemarujemo veličinu kategorije ili seta, što može dovesti do pristranosti zanemarivanja ekstenzije (Kahenman, 2000a). Primjeri ove kategorije pristranosti mogu se naći u tri tipa zadataka. Prvo, u procjeni vjerojatnosti da je pričljiva, pametna i cinična osoba odvjetnik u skupini ljudi od 30 odvjetnika i 70 inženjera; drugo, pri procjeni iznosa koji smo spremni platiti za spas 20000 ptica iz zagađenoga područja. Također, retrospektivne globalne procjene ugodnosti slušanja 30 glasnih zvukova odličan su primjer zanemarivanja ekstenzije. Naime, iako na prvi pogled nemaju ništa zajedničko, svi zadaci sadrže određeni broj elemenata - broj odvjetnika i inženjera, neugodnih trenutaka i ptica; i svi se tiču određenih prototipova prototip odvjetnika, neugodnoga trenutka ili ptice koja ugiba. 
DRUŠ. ISTRAŽ. ZAGREB GOD. 22 (2013), BR. 2, STR. 325-345

BOVAN, K.:

FORMIRANJE

GLOBALNE...
Budući da su za svaki navedeni zadatak važne informacije o veličini kategorije, odnosno broju elemenata, a prototipi ne sadrže te informacije, donošenje odluke na temelju prototipa dovodi do zanemarivanja temeljnog omjera (eng. base-rate), veličine uzorka ili trajanja, odnosno pristranostima u odlučivanju (detaljnije vidi u Kahneman i Frederick, 2002). ${ }^{2}$ Konkretnije, u slučaju zanemarivanja trajanja, prototipovi iskustva afektivna su stanja u trenutku vrhunca intenziteta i u trenutku kraja iskustva. Iako ljudi znaju trajanje iskustva, zanemaruju ga, pa retrospektivnu evaluaciju donose na temelju tih dvaju prototipova. Ovakav pristup gleda na zanemarivanje trajanja kao na pogrešku, jer - prema normativnom stavu trebamo uzeti u obzir trajanje prilikom donošenja procjene.

Međutim, postoje istraživači koji smatraju kako je zanemarivanje trajanja zapravo normativna pojava. Ariely i Loewenstein (2000) analiziraju proces evaluiranja te ističu dva cilja koja možemo imati prilikom davanja evaluacija - možemo prenositi informacije drugima o tome što nam se (ne) sviđa i možemo kodirati vlastite preferencije za upotrebu prilikom donošenja budućih odluka. Prilikom prenošenja informacija drugima postoje određene konverzacijske norme, od kojih je jedna relevantnost informacija (Miščević, 2003). Prema Arielyju i Loewensteinu (2000), evaluacije prošlih događaja bit će relevantne samo ako u njih ne ukomponiramo trajanje iskustva. Naime, ako u svoju procjenu uključimo i trajanje iskustva, mogli bismo reći svojem sugovorniku da nam je na putovanju bilo loše, premda se ono sastojalo od samo tri odlična dana, u odnosu na sedam odličnih dana. Uzevši u obzir konverzacijsku normu relevantnosti, rezultati istraživanja koji su pokazali postojanje zanemarivanja trajanja mogu se protumačiti kao produkt interpretacije pitanja što ih postavljaju sudionici, a ne stvarnoga zanemarivanja trajanja. Uz to, pitanjima o retrospektivnoj evaluaciji sudionici su morali izjavljivati, primjerice, o razini ugodnosti epizode (Frederickson i Kahneman, 1993) ili razini boli (Redelmeier, Katz i Kahneman, 2003), što su mogli shvatiti na više načina, jer ukupnost ugodnosti ili boli nisu dobro definirani pojmovi. Važniji argument za normativnost zanemarivanja trajanja tiče se kodiranja evaluacija za buduću upotrebu. Naime, ako bismo svoju evaluaciju putovanja temeljili, između ostalog, i na njegovu trajanju, prilikom odlučivanja o ponovnom putovanju koje bi imalo drugačije trajanje morali bismo parcijalizirati trajanje iz prvotne evaluacije i uzeti u obzir trajanje budućega putovanja. Uzevši u obzir kompliciranost ovakva procesa te činjenicu da većinu svojih procjena rabimo za buduće odluke, čini se normativnim, a ne pogreškom, zanemariti trajanje iskustva prilikom evaluacije prethodnih iskustava. Ariely i Loewenstein (2000) navode samo jedan tip situacija u kojima se zanemarivanje 
DRUŠ. ISTRAŽ. ZAGREB GOD. 22 (2013), BR. 2 STR. $325-345$

BOVAN, K.: FORMIRANJE GLOBALNE.. trajanja čini kao pogreška. To su rijetke situacije u kojima ljudi nisu sigurni u trajanje budućih iskustava te ga ne mogu kontrolirati, a jedino što znaju jest da traje otprilike isto kao i prvotno iskustvo. Dakle, autori se slažu s Kahnemanom da naše retrospektivne evaluacije ne sadrže trajanje, ali dok Kahneman smatra kako je zanemarivanje trajanja pogreška, odnosno pristranost, Ariely i Loewenstein smatraju kako je ono normativno i vrlo rijetko može dovesti do pogreške (Ariely i sur., 2000). Valja istaknuti slaganje autora oko procesne podloge zanemarivanja trajanja - slažu se kako je ono produkt faktora pažnje, a obje skupine smatraju kako trajanje iskustva utječe na evaluacije ako je trajanje salijentno (Ariely i sur., 2000).

\section{ALTERNATIVNO OBJAŠNJENJE FENOMENA - KOLIKO ČESTO ZAPRAVO ZANEMARUJEMO TRAJANJE?}

Nizom istraživanja utvrđeno je kako se retrospektivne evaluacije ne temelje na trajanju iskustva. Međutim, određeni nalazi doveli su u pitanje čestinu zanemarivanja trajanja u svakodnevnom životu, ali i ustaljeno teoretsko objašnjenje fenomena. Morewedge, Kassam, Hsee i Caruso (2009) smatraju kako je zanemarivanje trajanja specifična pojava koja je prisutna samo kada evaluiramo iskustva koja nam nisu poznata. Zanemarivanje trajanja, po mišljenju tih autora, ne temelji se na procesu pažnje, nego do njega dolazi kada nemamo referentnu usporedbu za trenutačno iskustvo. Ako provodimo pojedinačnu evaluaciju, a podražaj nam je poznat (poput jazz standarda), uspoređivat ćemo ga s poznatom skupinom podražaja s obzirom na relevantne karakteristike, među kojima je i trajanje. Ako nam podražaj nije poznat (poput zvukova u istraživanju Schreibera i Kahnemana (2000)), zanemarit ćemo njegovo trajanje i evaluaciju temeljiti na njegovim geštalt karakteristikama. Ako moramo odabrati među podražajima, neovisno o tome jesu li nam poznati ili ne, uspoređivat ćemo ih na temelju svih relevantnih karakteristika, među kojima je i trajanje, jer ćemo na temelju niza evaluacija stvoriti referentnu skupinu za uspoređivanje. Ova je pretpostavka u skladu s rezultatima istraživanja Arielyja i Loewensteina (2000), koji su pokazali kako zanemarivanje trajanja ovisi o vrsti procjene koju sudionici moraju dati. Sudionici su slušali nizove averzivnih zvukova, a četiri skupine sudionika razlikovale su se samo po vrsti procjena koje su davali - pojedinačna evaluacija, koliki su iznos novca spremni primiti da ponovno poslušaju niz, usporedba sa standardnim nizom i biranje koji od dva niza žele čuti ponovno. Sudionici su zanemarivali trajanje samo u slučaju pojedinačnih evaluacija, dok je na ostale vrste procjena utjecalo trajanje iskustva.

Kako bi izravno provjerili svoju hipotezu o poznatosti, Morewedge i suradnici (2009) proveli su tri istraživanja. U pr- 
DRUŠ. ISTRAŽ. ZAGREB GOD. 22 (2013), BR. 2, STR. 325-345

BOVAN, K.:

FORMIRANJE

GLOBALNE... vom su sudionici zamišljali putovanje u prepunom autobusu i procjenjivali neugodnost vožnje. Bili su podijeljeni u dvije skupine - jedna skupina redovito se vozila opisanim putem kojim je autobus "išao", a druga nije. Putovanje je moglo biti kratko ili dugo. Sudionici koji su bili upoznati s vožnjom duže su putovanje procjenjivali neugodnijim od kraćega, a ova razlika nije pronađena kod druge skupine. U drugom istraživanju sudionici su procjenjivali neugodnost zvukova koji su se razlikovali po trajanju (kratko i dugo) i po poznatosti (izmišljeni zvukovi i zvonjava telefona). Rezultati su pokazali da su sudionici dužu zvonjavu telefona procijenili neugodnijom nego kratku, a izmišljene zvukove procjenjivali su jednako neugodnima, neovisno o trajanju. Sudionici trećeg istraživanja procjenjivali su niz neugodnih zvukova. Iako su svi sudionici slušali isti kratki ili dugi niz zvukova, skupine su se razlikovale po zadanoj uputi - jednoj skupini rečeno je kako slušaju neobičnu zvonjavu telefona, a drugoj nije rečena kategorija zvuka. Sudionici kojima je niz zvukova predstavljen kao zvonjava duži su niz smatrali neugodnijim od kraćega, a ova razlika nije pronađena kod druge skupine sudionika.

Ovaj skup istraživanja dovodi u pitanje ustaljena teoretska objašnjenja (Ariely i sur., 2000). ${ }^{3}$ Naime, unatoč nesuglasicama o normativnosti zanemarivanja trajanja, svi autori slagali su se kako do toga fenomena dolazi zbog neusmjeravanja pažnje na atribut trajanja. Međutim, takva teoretska podloga ne nudi odgovarajuće objašnjenje za rezultate trećeg istraživanja (Morewedge i sur., 2009) - usmjeravanje pažnje na vrijeme ne bi trebalo ovisiti o tome jesu li podražaji sudionicima predstavljeni kao poznati ili ne. Čini se da do zanemarivanja trajanja dolazi kada podražaj ili iskustvo percipiramo kao nepoznato ili nam je ono doista nepoznato. Ako nam je kategorija podražaja poznata, imamo informaciju o distribuciji trajanja sličnih podražaja i bit ćemo osjetljivi na njegovo trajanje (Morewedge i sur., 2009). Prihvaćanje ovog objašnjenja dovodi u pitanje svakodnevnu prisutnost zanemarivanja trajanja. Naime, većina podražaja i iskustava s kojima se susrećemo poznata nam je, a čak i kada nije, zanemarit ćemo trajanje samo prilikom prvotne evaluacije.

Iz navedenih nalaza jasno je kako pojava zanemarivanja trajanja nije stabilna koliko se u početku smatralo. U skladu s tim, buduća istraživanja trebala bi ići prije svega u 2 smjera. Budući da se većina dosadašnjih tiče negativnih afekata, treba povećati broj eksperimentalnih provjera $\mathrm{u}$ sferi pozitivnih afekata. Naime, pozitivni i negativni afekt konceptualiziraju se kao nepovezani fenomeni (vidi, primjerice, Watson, Clark i Tellegen, 1988), pa je moguće da ne zanemarujemo trajanje kada proživljavamo ugodna iskustva. Uz to, nedostaju istraži- 
DRUŠ. ISTRAŽ. ZAGREB GOD. 22 (2013), BR. 2 STR. 325-345

BOVAN, K.: FORMIRANJE GLOBALNE.. vanja doživljaja koji se sastoje od kombinacije neugodnih i ugodnih perioda. Drugo, valja replicirati istraživanja Morewedgea i suradnika (2009). Kao što je već navedeno, rezultati tog istraživanja dovode $u$ pitanje raširenost pojave zanemarivanja trajanja. Dodatnim provjerama hipoteze poznatosti moći ćemo pouzdano prihvatiti, odnosno odbaciti, raširenost zanemarivanja trajanja. Istraživači se mogu usmjeriti na istraživanja u realnim uvjetima, koja, osim što imaju veću mogućnost poopćenja rezultata, iskorištavaju iskustva koja su ljudima poznata.

\section{PRAVILO VRHUNCA I KRAJA}

U opisanom istraživanju Varey i Kahneman (1992) pokazali su kako sudionici, prilikom donošenja globalne evaluacije iskustava, zanemaruju trajanje. Naknadnom analizom podataka Frederickson i Kahneman (1993) ustvrdili su kako se procjene sudionika mogu opisati prosjekom najintenzivnije trenutačne procjene i završne procjene neugodnosti - pojava je to koju su nazvali pravilom vrhunca i kraja (eng. peak-end rule). U svojem istraživanju, koje smo već detaljnije opisali, globalne afektivne procjene iskustva gledanja filmova, neovisno o trajanju filma, bile su dobro opisane prosjekom pravilom vrhunca i kraja. Drugim riječima, iako su filmovi trajali između 30 i 90 sekundi, sudionici su svoju evaluaciju temeljili na trenutačnim vrijednostima samo dvaju trenutaka. Pravilo vrhunca i kraja potvrđeno je u nizu istraživanja. Primjerice, sudionici su u jednom istraživanju gledali niz reklama koje su se razlikovale po tematici, trajanju i intenzitetu (Baumgartner i sur., 1997). Zadatak sudionika bio je da tijekom gledanja reklame pomicanjem kompjutorskoga miša označe svoje trenutačno afektivno stanje, a na kraju reklame morali su dati globalnu retrospektivnu evaluaciju reklame. Rezultati su pokazali kako su najintenzivniji trenutak i finalni trenutak bolje predviđali retrospektivnu evaluaciju od zbroja afektivnih reakcija svih trenutaka.

Pravilo vrhunca i kraja ispitivalo se i za iskustva koja se protežu kroz dulji period. ${ }^{4}$ Primjerice, $u$ jednom istraživanju sudjelovale su osobe koje boluju od reumatoidnog artritisa, kronične bolesti koja izaziva svakodnevnu bol. Sudionici su tijekom tjedan dana svakodnevno izjavljivali o trenutačnoj razini boli sedam puta dnevno, u nasumce raspoređenim intervalima. Nakon sedam dana morali su izjaviti o razini boli koju su osjetili u proteklih tjedan dana. Rezultati su pokazali kako je retrospektivna evaluacija odgovarala prosjeku najintenzivnije boli koju su sudionici osjećali tijekom tjedna i najintenzivnije boli zadnjega dana, što je u skladu s pravilom vrhun- 
DRUŠ. ISTRAŽ. ZAGREB GOD. 22 (2013), BR. 2, STR. 325-345

BOVAN, K.:

FORMIRANJE

GLOBALNE... ca i kraja (Stone, Broderick, Kaell, DelesPaul i Porter, 2000). U sličnom istraživanju pacijenti odjela za reumatologiju svaki su dan izjavljivali o svojim trenutačnim doživljajima boli te dnevnim evaluacijama boli u mjesec dana. U skladu s pravilom vrhunca i kraja, dnevne retrospektivne evaluacije odgovarale su prosjeku najintenzivnije i zadnje procjene boli (Schneider, Stone, Schwartz i Broderick, 2011).

Osim vrhunca i kraja, na retrospektivne odluke utječu i ostale navedene geštalt karakteristike (primjerice, trend ili brzina promjene), ali pravilo vrhunca i kraja čini se manje intuitivnim i može dovesti do paradoksalnih rezultata. Naime, pravilo vrhunca i kraja ima za posljedicu zanimljivu implikaciju - dodavanje umjereno neugodnoga podražaja na kraj niza smanjuje globalnu procjenu neugodnosti. Primjerice, niz trenutačnih procjena neugodnosti 2-5-8-4 sudionici su procjenjivali manje neugodnim od niza 2-5-8 (veći broj označuje veću razinu neugode; Varey i Kahneman, 1992). Ova pojava poznata je pod nazivom kršenje dominacije ${ }^{5}$ (eng. violation of dominance) i direktna je implikacija primjene pravila vrhunca $\mathrm{i}$ kraja (Kahneman, 2000a). Naime, u prvom nizu prosjek vrhunca i kraja (6) manji je nego u drugom slučaju (8), pa su stoga sudionici procjenjivali prvi niz ugodnijim, iako ukupna vrijednost prvoga niza upućuje na veću razinu neugode. $U$ istraživanju Kahnemana i suradnika (1993) sudionici su držali ruku u hladnoj vodi $\mathrm{u}$ dvije situacije. Kratka situacija trajala je 60 sekundi i temperatura vode bila je $14^{\circ} \mathrm{C}$, a druga situacija trajala je 90 sekundi, od čega je prvih 60 sekundi temperatura vode bila $14^{\circ} \mathrm{C}$, a 30 sekundi malo toplija, no i dalje neugodna. Drugim riječima, duža situacija bila je identična kratkoj situaciji, s razlikom da je sadržavala dodatnih 30 sekundi manje intenzivne boli. Nakon sudjelovanja u obje situacije sudionici su morali odabrati koje će iskustvo ponoviti. U skladu s pravilom vrhunca i kraja, većina sudionika odabrala je ponavljanje dužeg iskustva i potencijalno sebi priuštila veću količinu boli. Kršenje dominacije nije prisutno isključivo u domeni negativnih iskustava - dodavanjem umjereno ugodnih podražaja na kraj niza smanjuje se retrospektivna procjena ugodnosti. Primjerice, $\mathrm{u}$ jednom istraživanju sudionici su sudjelovanjem $u$ lutriji mogli osvojiti DVD filmove kao nagradu. Filmovi su bili svrstani u dvije liste - prva se sastojala od 10 filmova koje su kritičari proglasili izvrsnima, a druga od 10 filmova koje su kritičari proglasili umjereno dobrima. Najvažniji nalaz jest da su sudionici koji su dobili sjajan film i naknadno umjereno dobar film procjenjivali to iskustvo manje ugodnim od sudionika koji su dobili samo sjajan film (Do, Rupert i Wolford, 2008). 


\section{TEORETSKA PODLOGA PRAVILA VRHUNCA I KRAJA}

Pravilo vrhunca i kraja istraživalo se u paradigmi trenutačne evaluacije (Kahneman i sur., 1997). Prema toj paradigmi, vrhunac i kraj iskustva samo su dva trenutka cjelokupnog iskustva. Drugim riječima, vrhunac i kraj normativno se ne bi trebali razlikovati od bilo kojega drugog trenutka. U formiranju globalne retrospektivne evaluacije ti bi trenuci trebali imati jednaku "težinu". Međutim, niz rezultata naveo je Frederickson i Kahnemana (1993) da predlože tzv. fotografski model (eng. snapshot model), služeći se mišlju pisca Milana Kundere koji je rekao kako naša sjećanja ne izgledaju kao film nego kao niz fotografija (1991; prema Frederickson i Kahneman, 1993). Prema fotografskom modelu, evaluacije formiramo uz pomoć ponderiranoga prosjeka trenutaka, tako da svi trenuci, osim vrhunca i kraja, imaju nulti ponder, odnosno da samo vrhunac i kraj tvore "slike" u sjećanju. Zanemarivanje trajanja izravna je implikacija ovakva modela. Kahneman i njegovi suradnici (Kahneman, 2000a; Schreiber i Kahneman, 2000; Kahneman i Frederick, 2002) naknadno su fotografski model uklopili u načelo procjene prema prototipu. Kako smo već spomenuli, dva su prototipna trenutka na temelju kojih formiramo evaluacije, a ostale trenutke i trajanje pritom zanemarujemo.

Procjena prema prototipu dobra je paradigma za opis procesa evaluacije. Međutim, taj teoretski okvir ne nudi odgovor na pitanje zašto su vrhunac i kraj prototipni trenuci, odnosno zašto isključivo njima formiramo procjene. Potencijalni odgovor leži u principu evaluacije značenjem (eng. evaluation by meaning), prema kojem vrhunac i kraj prenose informacije koje su od osobnoga značenja za pojedinca i zbog toga se orijentiramo na njih (Frederickson, 2000). Vrhunac nam je važan jer prenosi informacije o najvećem intenzitetu iskustva i koliki mora biti afektivni kapacitet da se suočimo s epizodom. U skladu s ovom pretpostavkom jesu i rezultati istraživanja Frederickson i Kahnemana (1993), u kojima je vrhunac pri evaluaciji averzivnih filmova imao veći utjecaj od krajnjeg afekta. Također, vrhunac niza neugodnih slika (Branigan, Moise, Frederickson i Kahneman, 1997; prema Frederickson, 2000) i kvalitete televizijskog prijenosa (Hands i Avons, 2001) potpuno je predviđao retrospektivne evaluacije. Kraj smatramo važnim jer on znači da je iskustvo završeno i da ne postoji mogućnost za njegovu promjenu. Osim toga, krajnji doživljaj može promijeniti cjelokupno iskustvo - mukotrpno penjanje na vrh planine koje završi predivnim pogledom na dolinu smatrat ćemo pozitivnim iskustvom $u$ odnosu na sam uspon. Niz istraživanja potvrdio je da krajnje doživljaje smatramo važnima. Finn (2010) pokazala je kako studenti procjenjuju proces učenja ugodnijim ako nakon učenja teškoga gradiva slijedi raz- 
DRUŠ. ISTRAŽ. ZAGREB GOD. 22 (2013), BR. 2, STR. 325-345

BOVAN, K.:

FORMIRANJE

GLOBALNE.. doblje učenja umjereno teškoga gradiva nego kada toga razdoblja nema. Prilikom evaluacije parova iskustava koja se sastoje od identičnih dijelova pozitivnije procjenjujemo i iskustvo koje je započinjalo lošijim dijelom te završavalo boljim u odnosu na suprotno (Ross i Simonson, 1991; Loewenstein i Prelec, 1993). ${ }^{6}$ Važnost kraja potvrđena je i u evaluacijama kvalitete života i poznata je pod nazivom efekt Jamesa Deana. Naime, u skladu sa životom i smrti toga glumca, procjenjujemo kvalitetnijim život koji se sastoji od 30 godina sreće nego onaj koji se sastoji od dodatnih 30 godina manje razine sreće. Postoji i suprotna verzija ovog efekta - efekt Aleksandra Solženjicina očituje se u tendenciji da kvalitetnijim smatramo život od 30 teških i 30 manje teških godina u odnosu na onaj koji se sastoji od "samo" 30 teških godina (Diener, Wirtz i Oishi, 2001). Slično prilikom evaluacije moralnosti nečijega života imamo pristranost prema kraju života. Osobu koja je bila cijeli život sebična skloniji smo smatrati moralnijom ako je posljednju godinu života bila nesebična nego ako je nekad tijekom života bila godinu dana nesebična. Ova pristranost proizlazi iz pretpostavke da se "istinska, prava" osoba pojavljuje na kraju života (Newman, Lockhart i Keil, 2010).

\section{PRESKRIPCIJE}

Budući da ljudi evaluacije temelje na vrhuncu i kraju, poboljšanje kvalitete iskustva treba se temeljiti na promjeni ovih dvaju aspekata. Iako bi, teoretski, promjena u vrhuncu dovela do promjene kvalitete iskustva, na vrhunac je teško utjecati, pa su preskripcije usmjerene na poboljšanje krajnjega doživljaja. U skladu s rezultatima kršenja dominacije, mogli bismo osmisliti intervenciju kojom bi se poboljšala evaluacija iskustva. Primjerice, na kraju postupka popravljanja zuba zubar bi mogao nastaviti lagano dodirivati zub, što ne bi štetilo zubu i bilo bi manje neugodno nego ostatak postupka. Ovom bismo intervencijom iskustvo završili s manje neugodnim doživljajem, što bi trebalo "stvoriti" ugodnija sjećanja i potaknuti pojedinca da češće odlazi zubaru. Redelmeier i suradnici (2003) napravili su sličnu intervenciju - polovici pacijenata nad kojima je provedena kolonoskopija ostavili su uređaj u tijelu naknadne 3 minute i time im pružili manje neugodan kraj iskustva. Kao što se moglo i očekivati, ti su sudionici procjenjivali iskustvo pozitivnijim. Pravi "test" intervencije uslijedio je otprilike 5 godina kasnije, kada su autori stupili u vezu sa svim sudionicima i utvrdili jesu li u tom razdoblju ponovili proceduru. Nažalost, rezultati su pokazali kako je efekt bio zanemariv. Uz kontrolu značajnih faktora, poput rezultata prvotne kolonoskopije, samo $10 \%$ više sudionika eksperimentalne skupine $\mathrm{u}$ odnosu na kontrolnu skupinu ponovilo je proceduru. ${ }^{7}$ 


\section{PRAVILO VRHUNCA I KRAJA - RASPRAVA}

Opisani rezultati i teoretska objašnjenja pokazuju da postoji pravilo vrhunca i kraja kojim se vodimo prilikom formiranja globalnih evaluacija. Međutim, postoji niz prigovora koji dovode $u$ pitanje tu metodologiju i rasprostranjenost ovih nalaza u svakodnevici. Prvo, moramo reći kako je većina navedenih istraživanja koja su potvrdila postojanje pravila vrhunca i kraja bila na području negativnih afekata. Naime, postoji samo nekoliko istraživanja u sferi pozitivnih afekata koja su ga potvrdila (evaluacija televizijskih reklama, Baumgartner i sur., 1997, i popularne i klasične glazbe, Rozin i sur., 2004). ${ }^{8}$ Isto tako, ne postoji istraživanje kojim bi se ispitalo funkcioniranje pravila vrhunca i kraja kada se iskustvo sastoji od pozitivnih i negativnih emocija. Budući da se naša svakodnevica sastoji od niza pozitivnih i negativnih iskustava, to pitanje ostaje otvoreno. Najbliži odgovor nudi istraživanje u kojem su sudionici na godišnjem odmoru morali u slučajnim intervalima izjavljivati o trenutačnom zadovoljstvu. Nakon završetka odmora sudionici su davali svoje retrospektivne evaluacije zadovoljstva, a rezultati su pokazali kako vrhunac godišnjeg i kraj nisu značajno pridonosili globalnoj procjeni (Kemp, Burt i Furneaux, 2008). ${ }^{9}$ Uz navedeno, valja imati na umu kritiku Frederickson (2000), koja ističe kako se u svim istraživanjima na ovom području rabe jednodimenzionalne globalne mjere afekata, poput neugode-ugode ili negativno-pozitivno. Vrhunac i kraj mogu imati različito značenje kada smo u situaciji u kojoj osjećamo ljubav, mržnju ili gađenje. Dodatni prigovor "svakodnevici" ovoga pravila proizlazi iz pretpostavke Arielyja i Zaubermana (2000) o utjecaju segmentiranosti na globalne evaluacije. Naime, ti autori pretpostavljaju kako su naša svakodnevna iskustva segmentirana i kako se evaluacija više odvojenih iskustava ne temelji na geštalt karakteristikama, jer pamtimo isključivo globalne evaluacije pojedinih iskustava. Stoga su pretpostavili, i eksperimentalno potvrdili, kako evaluacija više iskustava odgovara prosječnoj vrijednosti pojedinačnih evaluacija, a ne prosjeku vrhunca i kraja (Ariely i Zauberman, 2000; Miron-Shatz, 2009). No najsnažnija kritika pravilu vrhunca i kraja jest da njegova predviđalačka snaga nije nimalo bolja od prosjeka trenutačnih evaluacija. Cojuharenco i Ryvkin (2008) prikupili su 54 seta podataka iz objavljenih i neobjavljenih istraživanja te pokazali kako su prosjek svih trenutačnih evaluacija i prosjek vrhunca i kraja u velikoj mjeri povezani te dovode do jednakih globalnih evaluacija. ${ }^{10}$ Navedene kritike upućuju na ograničenu raširenost pravila vrhunca i kraja u svakodnevici, a s najvećom sigurnosti možemo reći kako ono vrijedi za relativno kratka i negativna iskustva. Buduća istraživanja trebala bi se usmjeriti, ka- 
DRUŠ. ISTRAŽ. ZAGREB GOD. 22 (2013), BR. 2, STR. 325-345

BOVAN, K.:

FORMIRANJE

GLOBALNE..

\section{ZAKLJUČAK}

ko je navedeno, na pozitivna iskustva, ali i na kombinaciju negativnih i pozitivnih. Nadalje, očito je da ovo polje istraživanja ima mnogo potencijala za oblikovanje ponašanja. Preskripcijama se evaluacije neugodnih iskustava mogu poboljšati. Na taj način možemo povećati vjerojatnost da se ponovi neugodno, ali nužno, ponašanje, poput stomatološkoga zahvata. Budućim istraživanjima u realnim uvjetima trebalo bi se utvrditi koje preskripcije odgovaraju kojim iskustvima. Primjerice, valjalo bi provjeriti utjecaj segmentiranja dužeg iskustva na retrospektivnu globalnu evaluaciju.

Prilikom formiranja globalnih retrospektivnih evaluacija ljudi najčešće zanemaruju trajanje iskustva. Niz istraživanja potvrdio je prisutnost ovoga fenomena kod raznih iskustava, od gledanja televizijskih reklama (Baumgartner i sur., 1997) do jedenja hrane (Rode i sur., 2007). Umjesto na temelju prosjeka subjektivnih trenutačnih procjena, retrospektivne procjene temeljimo na manjem broju geštalt karakteristika iskustva, primjerice na trendu ili brzini promjene $\mathrm{u}$ intenzitetu iskustva (Ariely i Carmon, 2000). Niz istraživanja pokazao je i kako evaluacije temeljimo na ograničenom broju trenutačnih doživljaja. Konkretnije, procjenu temeljimo na prosjeku najintenzivnijega i krajnjega doživljaja ugode - pojava poznata pod nazivom pravilo vrhunca i kraja (Frederickson i Kahneman, 1993).

Iako navedeni rezultati jesu kontraintuitivni, i upravo zbog toga vrlo zanimljivi, postoji niz alternativnih teoretskih objašnjenja, ali i rezultata, koji nisu u skladu s dominantnim pretpostavkama (primjerice, Ariely i Loewenstein, 2000; Cojuharenco i Ryvkin, 2008; Morewedge i sur., 2009). Stoga valja biti oprezan prilikom zaključivanja kako su trenuci koji čine dosadan dan samo vrhunac i kraj.

\section{BILJEŠKE}

1 Određenje ukupne vrijednosti pretpostavlja niz uvjeta koje mjere trenutačne vrijednosti moraju ispuniti. Detaljnije vidi u Kahneman (2000b).

2 Valja naglasiti postojanje još jedne vrste zanemarivanja ekstenzije - aditioni efekt ekstenzije (eng. additive extension effect). U okviru zanemarivanja trajanja odnosi se na pojavu da sudionici pokazuju jednak uzorak reakcije na produljenje trajanja podražaja, neovisno o intenzitetu. Normativno valja očekivati multiplikativni efekt - produljenje podražaja višeg intenziteta trebalo bi rezultirati većom promjenom $u$ razini neugode nego $u$ slučaju produljenja slabijega podražaja (Schreiber i Kahneman, 2000).

3 Valja istaknuti i rad Lierscha i McKenziea (2009), koji su pokazali kako su rezultati istraživanja u kojem je prvotno pokazano zane- 
DRUŠ. ISTRAŽ. ZAGREB GOD. 22 (2013), BR. 2 STR. 325-345

BOVAN, K.: FORMIRANJE GLOBALNE.. marivanje trajanja (Varey i Kahneman, 1992) dijelom produkt načina prezentacije podataka. Naime, nizom eksperimenata pokazali su kako informacije na kojima sudionici temelje globalnu evaluaciju (prosjek ili pravilo vrhunca i kraja) ovise o grafičkim prezentacijama podataka. Iako su ovi rezultati zanimljivi, nisu toliko teoretski relevantni za sam fenomen, pa se njima nećemo potanje baviti.

4 Pravilo vrhunca i kraja čak se ispitivalo u neočekivanim domenama. Clark i Georgellis (2004) su pokazali kako najbolji prediktor davanja otkaza jest kombinacija najekstremnije i finalne procjene trenutačnog zadovoljstva poslom.

5 Valja imati na umu kako nalazi koji pokazuju kršenje dominacije nisu sami po sebi dokaz za zanemarivanje trajanja (Ariely i sur., 2000).

6 Standardni ekonomski model pretpostavlja da ljudi veću važnost pridaju iskustvima koja dolaze ranije u odnosu na kasnije. Pridavanje veće važnosti kasnijim iskustvima u bihevioralnoj je ekonomiji poznato pod nazivom negativni vremenski popust (eng. negative time discounting) (vidi Loewenstein i Prelec, 1993).

7 Međutim, čak i da su rezultati pokazali pozitivan efekt, postoji etička dvojba - je li opravdano intervenirati dodavanjem boli da bismo poboljšali zdravlje pojedinaca? Pitanje bi se zapravo moglo preformulirati - što je važnije - trenutačna ili retrospektivna vrijednost?

8 Uz navedene, istraživanje Rodea, Rozina i Durlach (2007), u kojem su sudionici iznosili trenutačne i retrospektivne evaluacije jela, nije potvrdilo postojanje pravila vrhunca i kraja.

${ }^{9} \mathrm{Na}$ globalne retrospektivne procjene i utječe činjenica jesu li osobe koje su donosile trenutačne procjene bile same ili je bilo prisutno još procjenjivača (detaljnije u Ramanathan i McGill, 2007).

10 Ovi rezultati mogu ukazivati na opravdanost korištenja pravila vrhunca i kraja kao adekvatne heuristike prilikom donošenja odluka. Ipak, autori ističu kako ovako visok stupanj povezanosti ovisi o stupnju međuovisnosti (primjerice razine adaptacije ili sidrenja) i stupnju heterogenosti reakcija pojedinaca. Više vidi u Cojuharenco i Ryvkin (2008).

\section{LITERATURA}

Ariely, D. (1998). Combining experiences over time: The effects of duration, intensity, changes and on-line measurements on retrospective pain evaluations. Journal of Behavioral Decision Making, 11(1), 19-45. doi:/10.1002/(SICI)1099-0771(199803)11:1<19::AID-BDM277>3.0. $\mathrm{CO} ; 2-\mathrm{B}$

Ariely, D. i Carmon, Z. (2000). Gestalt characteristics of experiences: The defining features of summarized events. Journal of Behavoral Decision Making, 13(2), 191-201. doi:/10.1002/(SICI)1099-0771(200004/ 06)13:2<191::AID-BDM330>3.3.CO;2-1

Ariely, D., Kahneman, D. i Loewenstein, G. (2000). Joint comment on "When does duration matter in judgment and decision making?". Journal of Experimental Psychology: General, 129(4), 524-529. doi:/10. 1037/0096-3445.129.4.524 
DRUŠ. ISTRAŽ. ZAGREB GOD. 22 (2013), BR. 2, STR. 325-345

BOVAN, K.:

FORMIRANJE

GLOBALNE...
Ariely, D. i Loewenstein, G. (2000). When does duration matter in judgment and decision making? Journal of Experimental Psychology: General, 129(4), 508-523. doi:/10.1037//0096-3445.129.4.508

Ariely, D. i Zauberman, G. (2000). On the making of an experience: The effects of breaking and combining experiences on their overall evaluation. Journal of Beavioral Decision Making, 13(2), 219-232. doi:/10. 1002/(SICI)1099-0771(200004/06)13:2<219::AID-BDM331>3.3.CO;2-G

Baron, J. (2008). Thinking and deciding. New York: Cambridge University Press.

Baumgartner, H., Sujan, M. i Padgett, D. (1997). Patterns of affective reactions to advertisements: The integration of moment-to-moment responses into overall judgments. Journal of Marketing Research, 34(2), 219-232. doi:/10.2307/3151860

Camerer, C., Loewenstein, G. i Prelec, D. (2005). Neuroeconomics: How neuroscience can inform economics. Journal of Economic Literature, 43(1), 9-64. doi:/10.1257/0022051053737843

Clark, A. E. i Georgellis, Y. (2004). Kahneman meets the Quitters: Peak-end behaviour in the labour market. CNRS and DELTA. Working paper. Cojuharenco, I. (2007). Lay intuitions about overall evaluations of experiences. Judgment and Decision Making, 2(1), 40-47.

Cojuharenco, I. i Ryvkin, D. (2008). Peak-end rule versus average utility: How utility aggregation affects evaluations of experiences. Journal of Mathematical Psychology, 52(5), 326-335. doi:/10.1016/j.jmp. 2008.05.004

Diener, E., Wirtz, D. i Oishi, S. (2001). End effects of rated life quality: The James Dean effect. Psychological Science, 12(2), 124-128. doi:/10.1111/ 1467-9280.00321

Do, A. M., Rupert, A. V. i Wolford, G. (2008). Evaluation of pleasurable experiences: The peak-end rule. Psychological Bulletin $\mathcal{E}$ Review, 15(1), 96-98. doi:/10.3758/PBR.15.1.96

Finn, B. (2010). Ending on a high note: Adding a better end to effortful study. Journal of Experimental Psychology: Learning, Memory and Cognition, 36(6), 1548-1553. doi:/10.1037/a0020605

Frederickson, B. L. (2000). Extracting meaning from past affective experiences: The importance of peaks, ends, and specific emotions. Cognition and Emotion, 14(4), 577-606. doi:/10.1080/026999300402808

Frederickson, B. L. i Kahneman, D. (1993). Duration neglect in retrospective evaluations of affective episodes. Journal of Personality and Social Psychology, 65(1), 45-55. doi:/10.1037//0022-3514.65.1.45

Hands, D. S. i Avons, S. E. (2001). Recency and duration neglect in subjective assessment of television picture quality. Applied Cognitive Psychology, 15(6), 639-657. doi:/10.1002/acp.731

Hsee, C. K. i Abelson, R. P. (1991). Velocity relation: Satisfaction as a function of the first derivative of outcome over time. Journal of Personality and Social Psychology, 60(3), 341-347. doi:/10.1037//0022-3514.60. 3.341

Hsee, C. K., Salovey, P. i Abelson, R. P. (1994). The Quasi-acceleration relation: Satisfaction as a function of the change of velocity of outcome 
DRUŠ. ISTRAŽ. ZAGREB GOD. 22 (2013), BR. 2 STR. $325-345$

BOVAN, K.: FORMIRANJE GLOBALNE.. over time. Journal of Experimental Social Psychology, 30(1), 96-111. doi:/10. 1006/jesp.1994.1005

Kahneman, D. (2000a). Evaluation by moments: Past and future. U D. Kahneman i A. Tversky (Ur.), Choices, values and frames (str. 693-708). Cambridge: Cambridge University Press.

Kahneman, D. (2000b). Experienced utility and objective happiness: A moment-based approach. U D. Kahneman i A. Tversky (Ur.), Choices, values and frames (str. 673-692). Cambridge: Cambridge University Press.

Kahneman, D. i Frederick, S. (2002). Representativeness revisited: Attribute substitution in intuitive judgment. U T. Gilovich, D. Griffin i D. Kahneman (Ur.), Heuristics and biases: The psychology of intuitive judgment (str. 49-81). Cambridge: Cambridge University Press.

Kahneman, D., Frederickson, B. L., Schreiber, C. A. i Redelmeier, D. A. (1993). When more pain is preferred to less: Adding a better end. Psychological Science, 4(6), 401-405. doi:/10.1111/j.1467-9280.1993.tb00589.x Kahneman, D., Wakker, P. P. i Sarin, R. (1997). Back to Bentham? Explorations of experienced utility. The Quarterly Journal of Economics, 112(2), 375-405. doi:/10.1162/003355397555235

Kemp, S., Burt, C. D. B. i Furneaux, L. (2008). A test of the peak-end rule with extended autobiographical events. Memory $\mathcal{E}$ Cognition, 36(1), 132-138. doi:/10.3758/MC.36.1.132

Langer, T., Sarin, R. i Weber, M. (2005). The retrospective evaluation of payment sequences: Duration neglect and peak-and-end effects. Journal of Economic Behavior E Organization, 58(1), 157-175. doi:/10.1016/ j.jebo.2004.01.001

Liersch, M. J. i McKenzie, C. R. M. (2009). Duration neglect by numbers - and its elimination by graphs. Organizational Behavior and $\mathrm{Hu}$ man Decision Processes, 108(2), 303-314. doi:/10.1016/j.obhdp.2008.07.001

Loewenstein, G. F. i Prelec, D. (1993). Preferences for sequences of outcomes. Psychological Review, 100(1), 91-108. doi:/10.1037//0033-295X. 100.1.91

Mirorn-Shatz, T. (2009). Evaluating multiepisode events: Boundary conditions for the peak-end rule. Emotion, 9(2), 206-213. doi:/10.1037/ a0015295

Miščević, N. (2003). Filozofija jezika. Zagreb: Jesenski i Turk.

Morewedge, C. K., Kassam, K. S., Hsee, C. K. i Caruso, E. M. (2009). Duration sensitivity depends on stimulus familiarity. Journal of Experimental Psychology: General, 138(2), 177-186. doi:/10.1037/a0015219

Newman, G. E., Lockhart, K. L. i Keil, F. C. (2010). "End-of-life" biases in moral evaluations of others. Cognition, 115(2), 343-349. doi:/10.1016/ j.cognition.2009.12.014

Ramanathan, S. i McGill, A. L. (2007). Consuming with others: Social influences on moment-to-moment and retrospective evaluations of an experience. Journal of Consumer Research, 34(4), 506-524. doi:/10. $1086 / 520074$

Redelmeier, D. A., Katz, J. i Kahneman, D. (2003). Memories of colonoscopy: A randomized trial. Pain, 104(1-2), 187-194. doi:/10.1016/S03043959(03)00003-4 
DRUŠ. ISTRAŽ. ZAGREB GOD. 22 (2013), BR. 2, STR. 325-345

BOVAN, K.:

FORMIRANJE

GLOBALNE...
Rode, E., Rozin, P. i Durlach, P. (2007). Experienced and remembered pleasure for meals: Duration neglect but minimal peak, end (recency) or primacy effects. Appetite, 49(1), 18-29. doi:/10.1016/j.appet.2006. 09.006

Ross, W. T. i Simonson, I. (1991). Evaluations of pairs of experiences: A preference for happy endings. Journal of Behavioral Decision Making, 4(4), 273-282. doi:/10.1002/bdm.3960040405

Rozin, A., Rozin, P. i Goldberg, E. (2004). The feeling of music past: How listeners remember musical affect. Music Perception, 22(1), 15-39. doi:/10.1525/mp.2004.22.1.15

Schneider, S., Stone, A. A., Schwartz, J. E. i Broderick, J. E. (2011). Peak and end effects in patients' daily recall of pain and fatigue: A within-subjects analysis. Journal of Pain, 12(2), 228-235. doi:/10.1016/j. jpain.2010.07.001

Schreiber, C. A. i Kahneman, D. (2000). Determinants of remembered utility of aversive sounds. Journal of Experimental Psychology: General, 129(1), 27-42. doi:/10.1037//0096-3445.129.1.27

Stone, A. A., Broderick, J. E., Kaell, A. T., DelesPaul, P. A. E. G. i Porter, L. E. (2000). Does the peak-end phenomenon observed in laboratory pain studies apply to real-world pain in rheumatoid arthritics? The Journal of Pain, 1(3), 212-217. doi:/10.1054/jpai.2000.7568

Varey, C. i Kahneman, D. (1992). Experiences extended across time: Evaluation of moments and episodes. Journal of Behavioral Decision Making, 5(3), 169-185. doi:/10.1002/bdm.3960050303

Watson, D., Clark, L. A. i Tellegen, A. (1988). Development and validation of brief measures of positive and negative affect: The PANAS scales. Journal of Personality and Social Psychology, 54(6), 1063-1070. doi:/10. 1037/0022-3514.54.6.1063

Wirtz, D., Kruger, J., Scollon, C. N. i Diener, E. (2003). What to do on spring break? The role of predicted, on-line, and remembered experience in future choice. Psychological Science, 14(5), 520-524. doi:/10. $1111 / 1467-9280.03455$

\section{Forming Global Retrospective Evaluation: Duration Neglect and the Peak-End Rule}

\section{Kosta BOVAN}

Zagreb

The impact of past experiences on decisions about the future depends on the evaluation of those experiences. When examining the relationship between ongoing and global affective ratings, the results indicate that global ratings of past affective experiences do not encompass information about the duration of an experience. In other words, people are prone to neglect duration. They usually follow the peak-end rule, basing their global rating just on the most intense and the last moment of an experience. In this article, the 
DRUŠ. ISTRAŽ. ZAGREB GOD. 22 (2013), BR. 2 STR. 325-345

BOVAN, K.

FORMIRANJE

GLOBALNE.. results of the most important experimental and real-world research are presented. Evaluation by moments and judgment by prototype paradigms along with the used methodology are described in detail. A discussion about normativity of duration neglect is brought up. Despite the fact that these phenomena have been found in a variety of areas, a series of studies and theoretical assumptions call into question their incidence. The article concludes with a discussion about potential prescriptions with which the quality of experiences could be improved.

Keywords: duration neglect, peak-end rule, real-time evaluation, evaluation by moments, judgment by prototype, affective evaluations 